\title{
Effects of Software Piracy on Economic Growth
}

\author{
Rodrigo Nobre Fernandez ${ }^{1}$, Felipe Garcia Ribeiro ${ }^{1} \&$ Jean Marcel Del Ponte Duarte ${ }^{1}$ \\ ${ }^{1}$ Department of Economics, Federal University of Pelotas, Pelotas, Brazil \\ Correspondence: Rodrigo Nobre Fernandez, Department of Economics, Federal University of Pelotas, Pelotas, \\ RS., M3A Brazil. E-mail: rodrigo.fernandez@ufpel.edu.br
}

Received: March 21, 2018

Accepted: April 6, 2018

Online Published: April 25, 2018

doi:10.5539/ijef.v10n6p1

URL: https://doi.org/10.5539/ijef.v10n6p1

\begin{abstract}
This study investigates the effects of software piracy on economic growth around the world for the years 2000 to 2014, using panel data structure with fixed effects to capture this relationship, plus year dummies. Our findings suggest, in general, that software piracy has a negative impact on growth and that this relationship seems to be non-linear.
\end{abstract}

Keywords: piracy, economic growth, panel data

\section{Introduction}

The fast technological development that has taken place in the last decades fostered an extremely important market in favour of the functioning and efficiency of computers: the software market. Just as the gains grow, losses also follow this direction, since this emerging industry presents some market problems, especially among them piracy, which influences mainly on the profit of the developer companies. According to the data of the Business Software Alliance (BSA), in 2013 software piracy was responsible for the loss of more than 62 billion dollars around the world. Keeping this problem in view, the importance was observed of promoting the debate on how the parties interested in that market, such as governments, developers, distributors and consumers, act when faced with the presence of copiers. In addition, the issue is relevant, due to the fact that countries are seeking for more investment in intellectual property rights protection, although there is no clear notion of the impacts of piracy on economic growth.

According to Andrés and Goel (2012) there are several ways in which software piracy can impact on growth. In the first place, it can take place through appropriability. Piracy fails to ensure the adequate return to the developer, ending up by reducing incentives for the development of new products. In the second place, it can impact in a negative way on productivity growth, which, in turn, affects growth. In the third place, the level of piracy can be seen as the level of institutional quality of the countries. Finally, piracy represents an investment risk in legal activities on the part of distributors, since there is a menace of not obtaining the desired returns. Therefore, that relation seems to take place, mainly, through technological progress, be it through fostering investment in research and development (R\&D), be it through the accumulation of human capital.

Keeping this in view, the models of economic growth do not consent on how this relation exactly takes place. The traditional neoclassic model does not include the technological progress, although the variable is mentioned, it is not explained, that is to say, it is determined exogenously, not clarifying the origin of the technological advances of the countries. The AK models, however, determine growth as endogenous, in that it depends on external factors such as accumulation of knowledge. The models do not make a clear distinction between capital accumulation and technological progress, however they serve to identify that there is a relationship between these variables and economic growth. On the other hand, the Schumpeterian models determine that technological progress takes place through competition among enterprises, through investment in $P \& D$, for the development of new products, over which the enterprise has the momentary monopoly on the technology until the next period in which a more modern product is developed. It encompasses the learning by investment effect. In general, economic models conclude that there is an impact of technology on economic growth. In this sense, this work investigates the effects of piracy on the growth of economies. To perform such task, the study by Andrés and Goel (2012) is extended in the following scope: i) an econometric data structure panel, with fixed effects is used, allowing to correct biases in the authors' estimations; ii) governance variables that capture the role of economic institutions are included; iii) the effects of economic shocks, as well as those of the 2008 crisis are controlled; iv) 
it is verified if the effect for the commercial value lost by the use of unlicensed software remains; and (v) the sample is stratified to verify whether the effect of piracy is different in developed and developing economies. In order to overcome the problem in question, as already mentioned, a structure of data in panel is explored for 95 countries within the period between 2000 and 2014, and equations estimated that relate the GDP growth to software piracy by controlling for fixed country effects. The identification hypothesis for the establishing of a causal relationship is that the unobservable factors correlated with software piracy and GDP growth simultaneously are fixed throughout time. Social norms and institutions, for example, are two of the possibly unobservable factors that are correlated with piracy and economic growth and can be reasonably characterized as fixed over time because they vary little over short time frames (Glaeser, La Porta, Lopes de Silanes, \& Sheleifer, 2004).

The results indicate that there is a negative impact, due to piracy, on the economic growth up to a certain point, since that relation seems to present itself in a convex way. That result is significant, especially for developed countries. On the other hand, for the independent variable of commercial losses, the impact is positive up to a certain point, since the result indicates a concave relationship.

In this way, this work is structured into five sections, beginning with this introduction. In the second part is the literature revision. Immediately after is the presentation of the methodology and data. Finally, the results are shown and it is closed with the final considerations.

\section{Literature Revision}

Some authors highlight the importance of human capital for economic growth. It is the case of Schultz (1963), who stressed the importance of the inclusion of human capital in economic growth models. In this sense, Lucas (1988) emphasized the relevance of that variable when including it in his own models.

Romer (1990) analyzed the relation between human capital and growth. The relationship is given in an indirect way, once the initial level of literacy affects the level of investment, which in turn explains the rate of economic growth. Another piece of evidence on this issue is given by Barro (2001). The author emphasizes the importance of education on growth, distinguishing quantity of quality, measured by the marks in international tests. Although quality may have a higher effect, both points have a positive influence. Besides this, workers with a higher education level would be more efficient with the complementation of new technologies. In this context it is the technological development that possesses an important role on economic growth.

The economic literature allows software piracy to be seen as an illegal activity that affects the economy. Becker (1974) incorporated combat policies towards illegal attitudes in the maximizing problem of the economy. Punishing offenders, for example, also generates a cost to society. Another illegal activity that has an effect on growth is corruption. According to Mauro (1995) that practice reduces private investment which, on its hand, reduces economic growth. These are examples of practices that are a reflection of the institutional quality of countries.

Barro and Lee (1994), studied the economic growth determiners, among them a group of variables that represent market distortions. According to the authors, that variable, besides others such as size of the government and their consumption rate, possess a negative impact on the economic growth. On the other hand, the gross investment rate of GDP has a positive impact on this same dependent variable. Differently, a number of researchers have discussed the relationship of intellectual property rights protection on growth, as the discussion of how intellectual property rights affect the business environment is a frequent pattern among policymakers and researchers. In this sense, Yang (2007) analysed the relation between the business atmosphere and software piracy. One of the highlighted elements is the participation of the countries in intellectual property protection organizations (IPI). According to the authoress, the participation in the IPI strengthens the protection of intellectual property rights, which is extremely important in the combat of piracy, since the diffusion of technology among countries occurs very quickly. The researcher concluded that IPI has an impact only in countries of "low piracy", that is to say, developed countries are more concerned with global recommendations on a better copyright protection environment. Another piece of evidence on this topic is that the more developed economies tend to present a higher level of patent protection. Ginarte and Park (1997) worked on this subject when they created an index of patent rights, seeking to identify which factors have an influence on the maintenance of these rights. In the meantime, it is not the level of development of a nation that determines the provision of patent rights but yes, the economic development determiners, such as the free market, open trade, etc. Therefore, the relationship between economic development and piracy, this being measured through the levels of intellectual protection, are once more emphasized.

Falvey, Foster, and Greenaway (2006) provide an additional empirical foundation regarding the protection of 
intellectual property and their impact on economic growth. The researchers observed that there are several channels through which countries can innovate, and that each one gives importance to this fact according to their level of development. Since the protection of patent rights influences directly on technological innovation, hence this is directly associated to the development level of the country.

Further evidence on this subject is given by Kim, Lee, and Park (2012). According to the authors, greater protection of property rights increases economic growth, stimulating investment in R\&D area, only in developed countries (with a statistically insignificant effect for developing countries). This is because the nature of R\&D is different for different levels of economic development.

Besides the investment in IPI reducing piracy, some other socioeconomic factors also affect it. Among the simplest relations, Gomes et al. (2015) found the relation of variables such as education and per capita GDP with lower levels of piracy, although with inequality, this relation is negative. But there are more complex variables to measurewhich also affect growth, and are not observed, such as cultural issues. Therefore, in order to be more effective in preventing illegal copying, it is necessary to better understand the scenario. The educational issue is highlighted by Jeong and Khouja (2013). Following, in line with the fight against piracy, some authors debate that in addition to investing in IPI, there are other ways of doing so. Rao and Klein (1994) believe that legal protection of software - especially through copyright protection - loses its efficiency over time. Instead of this, the enterprises should seek for other methods, such as alliances and diversification of products. Kogan et al (2013) include, besides price strategies, the tactic of periodic updates of the softwares in which it is possible to maximize profit.

On the other hand, there are some studies in the literature that present positive effects of piracy on the growth through diverse ways. One of the ways in which piracy generates positive externalities is by increasing the user base. The issue of diffusion is discussed by Prasad and Mahajan (2003), where there is an optimum level of piracy according to the type of market, determined by the choice of how much the company should protect itself from illegal copies. That aspect is also investigated by Minniti and Vergari (2010), who highlight that this effect is more captured still in developing markets, showing through and analyzing how a community of archive sharing affects the profitability of producers of digital goods. In addition, piracy can produce other positive effects, such as signalling and herding effects (Note 1) (Castro et al., 2008). King and Lampe (2002) mention the possibility of profit maximization when allowing a certain level of piracy (under some hypothesis), since it is not possible to discriminate prices among pirates and legal consumers. That possibility was also confirmed under another viewpoint. Liu et al (2011) showed that, when incorporating the empirical results generated by the diffusion, it is possible to develop an optimal price policy that maximizes the profit, by treating in more than one period.

Some other authors sought to analyse the favourable consequences of piracy in aggregated social terms. Banerjee and Chatterjee (2010) made an analysis in relation to the R\&D investment. Assuming that the probability of innovation depends on the level of investment in $R \& D$, monopolistic firms have a delay in the incentive to innovate, in addition to a loss in the company's profit.

However, when there is a competitive market in which firms have different levels of investment, piracy reduces the degree of investment of the most efficient company, while increasing the others, increasing the overall probability of innovation being successful. Then, Waters (2015) discussed the effects on general welfare in an already stabilized (or fixed-size) market, but with an opposite effect in emerging markets. That is because the second can hardly confront piracy delaying the launching of the product, while the first can do it through price strategies. In markets in which the cost of monitoring piracy through the government is higher than the gross social benefit, it does not have the incentives to combat piracy in a dedicated manner, nor does it prevent the company from becoming monopolistic (Sánchez 2010). Therefore, the enterprise must focus not only on the government's attitude, but also in their own price strategies in order to avoid the entrance of pirates in the market.

In the meantime, piracy can have different effects in the short run as well as in the long run. In the short run, the threat of piracy reduces the price of the product, thus increasing the consumption of authorized copies. However, in the long run, the existence of piracy reduces the quality of the product, which can be mitigated by an increase in the IPI, according to Bae and Choi (2006). Jaisingh (2009) also claimed that a rigorous policy against piracy can increase it, besides reducing the quality of the product, through the cost of using software for the final consumers. Bezmen and Depken (2004) empirically analysed the relation between piracy and growth. The evidence showed a negative correlation between the variables. Authors used the Human Development Index, supplied by the United Nations Organization end the piracy rate of the BSA. 
Andrés and Goel (2012) analysed the impact of piracy on development. The authors used the instrumental variables method to assess this issue. According to the researchers, there is a negative impact of piracy on the GDP per capita, that is to say, the higher the level of software imitation, the lower the economic growth of a country, in spite of the relation not being linear. This occurs, since in low levels of piracy there is growth retardation while at higher levels there is a network of externalities that cushion that effect. The authors, meanwhile, believe that there is endogeneity between piracy and growth. They are tempted to overcome the problems instrumenting the software piracy variable through the proportion of people with access to the Internet and by the index of patent rights. However, it is believed that these variables, used as instruments, do not meet the hypothesis of exogeneity. For example, countries with higher GDP growth are more likely to experience higher spending on infrastructure, which in turn can improve the supply of public and private services including Internet services that affect the proportion of users. That possibility, besides others, make that these instrumental variables do not meet the fundamental assumption of exogeneity for the estimations to establish causal links.

Given the evidence presented in the literature, the following are the methodology and data that allow us to evaluate if there is a causal relationship between economic growth and piracy rate.

\section{Data and Methodology}

The main source of data related to software piracy are the BSA reports, which is an international organization that represents several of the major software companies worldwide. Regarding economic variables, the economic and governance development indicators of the World Bank were used. With the aim of testing the effect of software piracy and the commercial losses due to the commercialization of unlicensed software in commercial growth, the period of time selected was from 2000 to 2014.

Regarding the variables in table 1 it is important to make some considerations. The logarithm of the variables that were not in percentage terms, that is, of the commercial loss generated by the installation of pirated software (loss) and GDP per capita (gdppc) are taken.

Table 1. Summary of the variables

\begin{tabular}{ccl}
\hline Variable & Label & \multicolumn{1}{c}{ Definition } \\
\hline Piracy & piracy & Reason for total unlicensed software by the amount of software installed \\
\hline Commercial losses with Illegal Software & loss & Commercial value of total unlicensed software that is installed \\
\hline Growth of GDP per capita & gdpgr & Annual growth of GDPper capita \\
\hline GDP per capita & gdppc & GDP per capita based on purchasing power parity. Computed to 2011 constant Dollars. \\
\hline Gross Capital Formation (\% of GDP) & gdi & $\begin{array}{l}\text { Gross capital formation is composed by expenditures on fixed assets of the economy } \\
\text { plus net changes in the level of inventories. }\end{array}$ \\
\hline Workforce Growth & glab & Comprises the annual growth in the labor supply of people aged 15 and over \\
\hline Literacy rate & lit & It is the percentage of people from 15 years old who can read and write \\
\hline Education Expenses (\% GNI) & geduc & $\begin{array}{l}\text { Refers to operating expenses in education, including wages and salaries and excluding } \\
\text { capital investments in buildings and equipment. }\end{array}$ \\
\hline Participation and Responsibility & $\begin{array}{l}\text { It captures the perception of the extent to which the citizens of a country are able to } \\
\text { participate in the choice of their government, as well as freedom of expression, } \\
\text { freedom of association, and a free media. }\end{array}$ \\
\hline vule of law & $\begin{array}{l}\text { It captures the perception of how agents rely on the validity of society's rules, and in } \\
\text { particular the quality of enforcement of contracts, property rights, police and in court, } \\
\text { as well as the likelihood of crime and violence. }\end{array}$ \\
\hline
\end{tabular}

Source: Prepared by the authors based on BSA (2007, 2009 and 2013) and the Governance and Economic Development Indicators of the World Bank.

The estimation of equations that relate economic performance (GDP growth) against software piracy cannot be performed by the classical Ordinary Least Squares (OLS) method. This stems from the fact that there are unobservable factors simultaneously correlated with economic performance and software piracy. In addition, the endogeneity of equations of this type may be thought to be the result of a simultaneous equations model where at the same time that software piracy determines economic performance, economic performance also leads to software piracy. In view of this problem, the use of alternative strategies is necessary for the identification of the causal impact of software piracy on economic growth.

As already discussed in the introduction, the evidence that exists in the literature is available in the work of Andrés and Goel (2012) and based upon the method of instrumental variables (two-stage estimation). The 
instruments the authors use, which are proportion of Internet users and patent right index, however, can hardly be considered as exogenous. As already discussed, it is possible that economic performance affects the instruments, or that there are unobservable factors, such as social norms and institutions, that are correlated with the instrument and affect economic performance. Being this so, the estimations presented by the authors are probably biased, not delivering the causal effect of software piracy on economic growth, which is fundamental for the marking-out of the cost and benefit analysis of any anti-piracy policy.

It is necessary to say that finding an adequate instrumental variable for the problem in question is not an easy task. Therefore, in this study, the empirical strategy is based on another method but, believed to be adequate to address the problem in question since it is believed that its identification hypothesis is credible. This is the fixed effects method. With virtually the same database of Andrés and Goel (2012) in terms of analysis units (countries), variables and period, the data panel structure is explored instead of using a cross-section of averages as the authors did. Being thus so, it is possible to control by the unobservable factors that are simultaneously correlated with software piracy and economic performance.

The hypothesis for identifying the impact of interest is that all unobservable factors that cause confusion in identifying the causal impact between piracy and economic growth, are precisely those that are fixed over time, and are controlled. In the present case, it makes sense to imagine that such factors might be social norms and institutions, although in some specifications there are controls for institutions.

Formally, the estimated equation is the following:

$$
y_{i t}=\alpha_{i}+\lambda_{t}+\delta P I_{i t}+X_{i t} \beta+\varepsilon_{i t}
$$

The variable $y_{i t}$ represents the growth of the GDP of country $i$ in year $t . P I_{i t}$ is the piracy variable of country $i$ in year $t$. Yet $X_{i t}$ contains the covariates, important variables to explain the economic growth of the countries. Among the covariates we have, GDP per capita, gross capital formation (\% of GDP), Labor force growth, literacy rate, education expenditure (\% GNI), participation and accountability, and the Rule of law. But the term $\alpha_{i}$ captures the non-observable fixed components, fixed over time that is believed to be the source of confusion for the identification of the impact of software piracy on economic growth. Finally, $\lambda_{t}$ represents the dummies of the year to capture shocks over time that affect all observations in the same way. Additionally, the following version of the equation below is also estimated:

$$
y_{i t}=\alpha_{i}+\lambda_{t}+\delta P I_{i t}+\chi P I_{i t}^{2}+X_{i t} \beta+\varepsilon_{i t}
$$

The term $P I_{i t}{ }^{2}$ allows the investigation of nonlinearities of the effect piracy on economic growth. In short, piracy can reduce economic growth to declining rates. A possible explanation for this relation is that small levels of piracy reduce the growth by means of investment but, if piracy grows, up to a limit, the decrease in the GDP growth rate is smaller when compared with that increase. This can happen due to the effects of network externalities or overflow resulting from piracy. Here is what was also done by Andrés and Goel (2012).

Additionally, the same estimations of (1) and (2) are also performed replacing the piracy variable by the amount in millions of dollars lost by the use of illegal software. Besides that, equations (1) and (2) are also estimated for sub-samples of countries depending on their degree of development. This is done to check the existence of possible heterogeneous effects of software piracy on economic growth due to the countries' previous level of development.

\section{Results}

The results of the regressions are presented below. It should be noted that we have an unbalanced panel with 95 countries for the period from 2000 to 2014. In addition, year 2000 was used as reference year for all estimates. The initial idea was to use as a variable, one that controlled the effect of education, the percentage of literate individuals - 15 or more years old. However, due to the large presence of "missings" in the referred database, we chose to use for this purpose the variable for education expenditures as a percentage of Gross National Income. 
Table 2. Growth and piracy - with a different control for education

\begin{tabular}{|c|c|c|c|c|c|}
\hline & (1) & (2) & (3) & (4) & (5) \\
\hline \multirow[t]{2}{*}{ gdi } & $0.3828^{* * *}$ & $0.3750^{* * *}$ & $0.3922^{* * *}$ & $0.3759^{* * *}$ & $0.3750^{* * * *}$ \\
\hline & $(0.0641)$ & $(0.0741)$ & $(0.0642)$ & $(0.0752)$ & $(0.0758)$ \\
\hline \multirow[t]{2}{*}{ geduc } & 0.0849 & 0.0759 & 0.1287 & 0.1201 & 0.1145 \\
\hline & $(0.2699)$ & $(0.2756)$ & $(0.2725)$ & $(0.2908)$ & $(0.2871)$ \\
\hline \multirow[t]{2}{*}{ piracy } & $0.1852^{* * *}$ & $0.1909^{* * *}$ & -0.1135 & -0.1928 & -0.2028 \\
\hline & $(0.0347)$ & $(0.0361)$ & $(0.1344)$ & $(0.1258)$ & $(0.1355)$ \\
\hline \multirow[t]{2}{*}{ labgr } & $-0.3274^{* * *}$ & $-0.3290^{* * * *}$ & $-0.3160^{* * * *}$ & $-0.3165^{* * *}$ & $-0.3154^{* * *}$ \\
\hline & $(0.0923)$ & $(0.0907)$ & $(0.0912)$ & $(0.0876)$ & $(0.0886)$ \\
\hline \multirow[t]{2}{*}{ lgdppc } & & 1.2126 & & 2.9957 & 3.1272 \\
\hline & & $(2.1826)$ & & (2.1483) & $(2.2842)$ \\
\hline \multirow[t]{2}{*}{ piracy2 } & & & $0.0023^{* *}$ & $0.0030^{* * * *}$ & $0.0030^{* * * *}$ \\
\hline & & & $(0.0011)$ & $(0.0011)$ & $(0.0011)$ \\
\hline \multirow[t]{2}{*}{ voice } & & & & & -0.0299 \\
\hline & & & & & (1.0677) \\
\hline \multirow[t]{2}{*}{ rule } & & & & & -0.4228 \\
\hline & & & & & $(1.2609)$ \\
\hline Year Dummies & Yes & Yes & Yes & Yes & Yes \\
\hline$N$ & 910 & 910 & 910 & 910 & 910 \\
\hline adj. $R^{2}$ & 0.415 & 0.415 & 0.420 & 0.422 & 0.421 \\
\hline
\end{tabular}

Note. Robust Standard Errors between parentheses. * significant at 10\%,** significant at 5\%, and *** significant at $1 \%$. We use temporal dummies in all models.

Changing the control to education achieves a significant increase in the number of observations. This result shows that the variable piracy squared has a positive and significant effect, which may indicate that a convex functional form between piracy and the explained variable, although the coefficient is low. The piracy variable presented statistical significance only in models (1) and (2), which did not have the squared piracy variable. However, it is not possible to interpret this result, since the fact that the square pirate variable is significant may represent a poor specification of the model in the case of the omission of such.

From that point, this specification is used as a standard. The next step is to verify the effect of the loss (measured in millions of dollars) of commercial value on the use of pirated software in per capita product growth.

Table 3. Growth and piracy - with a different control for education and loss variable

\begin{tabular}{|c|c|c|c|c|c|}
\hline & $(1)$ & $(2)$ & $(3)$ & $(4)$ & $(5)$ \\
\hline \multirow[t]{2}{*}{ gdi } & $0.3762^{* * *}$ & $0.3797^{* * * *}$ & $0.3861^{* * *}$ & $0.3838^{* * *}$ & $0.3803^{* * *}$ \\
\hline & $(0.0727)$ & $(0.0804)$ & $(0.0721)$ & $(0.0796)$ & $(0.0796)$ \\
\hline \multirow[t]{2}{*}{ geduc } & 0.0461 & 0.0489 & 0.0111 & 0.0081 & -0.0143 \\
\hline & $(0.2925)$ & $(0.2844)$ & $(0.2535)$ & $(0.2528)$ & $(0.2488)$ \\
\hline \multirow[t]{2}{*}{ lloss } & 0.1468 & 0.1891 & $1.3339^{* * *}$ & $1.3358^{* * *}$ & $1.2430^{* * *}$ \\
\hline & $(0.3815)$ & $(0.3408)$ & $(0.4661)$ & $(0.4660)$ & $(0.4734)$ \\
\hline \multirow[t]{2}{*}{ labgr } & $-0.3216^{* * *}$ & $-0.3201^{* * *}$ & $-0.3365^{* * *}$ & $-0.3380^{* * *}$ & $-0.3396^{* * *}$ \\
\hline & $(0.1036)$ & $(0.1038)$ & $(0.1026)$ & $(0.1023)$ & $(0.1012)$ \\
\hline \multirow[t]{2}{*}{ lgdppc } & & -0.7036 & & 0.5120 & 0.9885 \\
\hline & & $(2.5466)$ & & $(2.5893)$ & (2.7188) \\
\hline \multirow[t]{2}{*}{ lloss 2} & & & $-0.1663^{* * *}$ & $-0.1708^{* * *}$ & $-0.1713^{* * *}$ \\
\hline & & & $(0.0433)$ & $(0.0485)$ & $(0.0483)$ \\
\hline \multirow[t]{2}{*}{ voice } & & & & & 0.7093 \\
\hline & & & & & (1.2197) \\
\hline \multirow[t]{2}{*}{ rule } & & & & & -1.6074 \\
\hline & & & & & $(1.1305)$ \\
\hline Year Dummies & Yes & Yes & Yes & Yes & Yes \\
\hline$N$ & 902 & 902 & 902 & 902 & 902 \\
\hline adj. $R^{2}$ & 0.390 & 0.390 & 0.398 & 0.397 & 0.398 \\
\hline
\end{tabular}

Note. Robust Standard Errors between parentheses. * Significant at 10\%, ** significant at 5\%, and *** significant at $1 \%$. We use temporal dummies in all models. 
It can be observed that the loss due to non-commercialization of the licensed software has a positive and significant effect on the per capita income growth. This effect is only confirmed in models (3), (4) and (5), and their magnitude is little changed. In addition, the quadratic term has a different sign than the piracy variable, indicating a possible concave relationship between per capita GDP growth and the commercial loss generated by the use of unlicensed software. In other words, to some extent, this use would cause the GDP to grow, after reaching this value; the additional increase would entail a reduction in the growth of per capita income.

Differently from Andrés and Goel (2012) it is verified if the effect of piracy is different in developed and developing countries performing two sub-samples for these groups of nations. The results of these estimates are presented in table 4:

Table 4. Growth and piracy - developed countries

\begin{tabular}{|c|c|c|c|c|c|}
\hline & (1) & (2) & (3) & (4) & (5) \\
\hline \multirow[t]{2}{*}{ gdi } & $0.3330^{* * * *}$ & $0.3198^{* * *}$ & $0.3436^{* * *}$ & $0.3160^{* * *}$ & $0.3195^{* * * *}$ \\
\hline & $(0.0485)$ & $(0.0614)$ & $(0.0493)$ & $(0.0597)$ & $(0.0606)$ \\
\hline \multirow[t]{2}{*}{ geduc } & 0.1078 & 0.1118 & 0.1451 & 0.1698 & 0.1939 \\
\hline & $(0.2620)$ & $(0.2624)$ & $(0.2771)$ & $(0.2838)$ & $(0.2785)$ \\
\hline \multirow[t]{2}{*}{ piracy } & $0.1826^{* * * *}$ & $0.1876^{* * *}$ & -0.1365 & $-0.2553^{*}$ & $-0.2449^{*}$ \\
\hline & $(0.0517)$ & $(0.0515)$ & $(0.1595)$ & $(0.1341)$ & $(0.1393)$ \\
\hline \multirow[t]{2}{*}{ labgr } & $-0.3010^{* * *}$ & $-0.3000^{* * *}$ & $-0.2935^{* * *}$ & $-0.2880^{* * *}$ & $-0.2839^{* * *}$ \\
\hline & $(0.0957)$ & $(0.0933)$ & $(0.0944)$ & $(0.0888)$ & $(0.0900)$ \\
\hline \multirow[t]{2}{*}{$\operatorname{lgdppc}$} & & 1.7776 & & $4.2662^{*}$ & 4.2221 \\
\hline & & $(2.7233)$ & & $(2.4335)$ & (2.6783) \\
\hline \multirow[t]{2}{*}{ piracy2 } & & & $0.0025^{*}$ & $0.0035^{* * *}$ & $0.0035^{* * *}$ \\
\hline & & & $(0.0014)$ & $(0.0012)$ & $(0.0013)$ \\
\hline \multirow[t]{2}{*}{ voice } & & & & & -1.0537 \\
\hline & & & & & $(1.1591)$ \\
\hline \multirow[t]{2}{*}{ rule } & & & & & 0.9405 \\
\hline & & & & & $(1.3392)$ \\
\hline Year Dummies & Yes & Yes & Yes & Yes & Yes \\
\hline$N$ & 686 & 686 & 686 & 686 & 686 \\
\hline adj. $R^{2}$ & 0.478 & 0.479 & 0.485 & 0.490 & 0.490 \\
\hline
\end{tabular}

Note. Robust Standard Errors between parentheses. * Significant at $10 \%, * *$ significant at $5 \%$, and $* * *$ significant at $1 \%$. We use temporal dummies in all models.

It can be noticed that the effects of piracy do not change much in models (1) and (2) for developed countries. However, its coefficient changes sign in models (3), (4) and (5) as well as that of its quadratic term. In short, piracy can have a smaller positive effect in already developed countries or a strictly negative effect. The actual gain from using pirated software is lower if it is considered that these nations have a higher income level.

In this sense, the effects of piracy on developing countries are also evident. However, no evidence was found to confirm any effect when analysed exclusively in this group of countries. Table 5 expresses these results:

Table 5. Growth and piracy - developing countries

\begin{tabular}{lccccc}
\hline & $(1)$ & $(2)$ & $(3)$ & $(4)$ & $(5)$ \\
\hline gdi & $0.4023^{* *}$ & $0.4230^{* *}$ & $0.3971^{* *}$ & $0.4160^{* *}$ & $0.4105^{* *}$ \\
& $(0.1513)$ & $(0.1567)$ & $(0.1508)$ & $(0.1576)$ & $(0.1534)$ \\
geduc & -0.5323 & -0.4830 & -0.4023 & -0.3635 & -0.3699 \\
& $(0.7352)$ & $(0.6114)$ & $(0.7168)$ & $(0.6043)$ & $(0.5984)$ \\
piracy & 0.1110 & 0.0418 & -1.4672 & -1.4606 & -1.2095 \\
& $(0.0712)$ & $(0.1163)$ & $(0.9450)$ & $(0.9467)$ & $(0.8846)$ \\
labgr & -0.3384 & -0.2778 & -0.2346 & -0.1844 & -0.1955 \\
& $(0.3243)$ & $(0.3497)$ & $(0.2747)$ & $(0.2975)$ & $(0.2932)$ \\
lgdppc & & -4.6385 & & -4.1826 & -4.3020 \\
& & $(3.3069)$ & & $(3.4151)$ & $(3.5024)$ \\
\hline
\end{tabular}




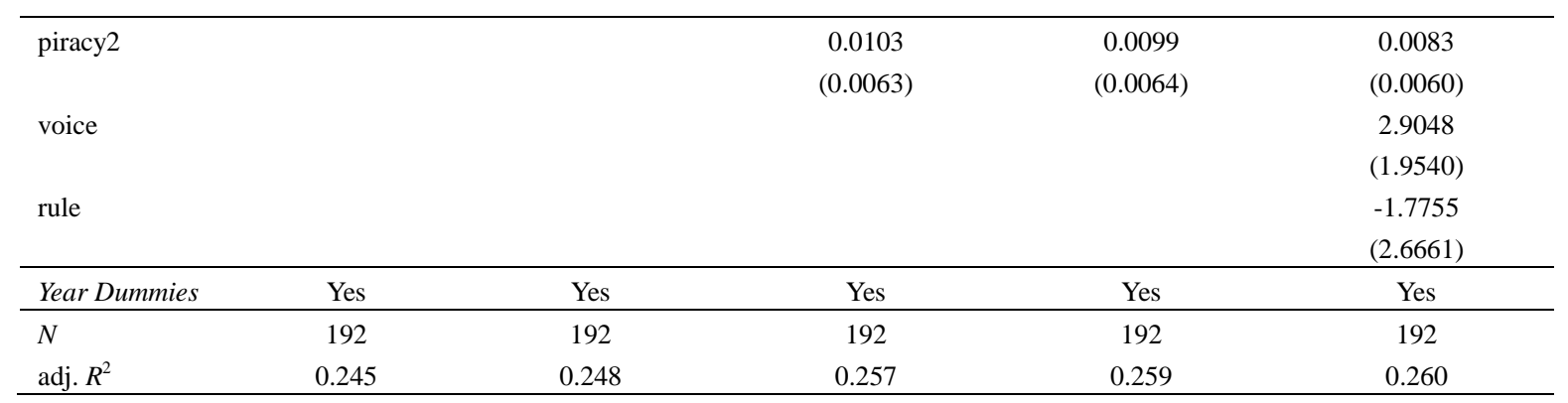

Note. Robust Standard Errors between parentheses. * Significant at 10\%,** significant at 5\%, and *** significant at $1 \%$. We use temporal dummies in all models.

The analysis for loss of commercial value for the installation of unlicensed software is resumed. Note that in models (3), (4) and (5) the effect is contrary to that of the variable piracy. There is a concave shape between the variable loss and GDP growth. In other words, there is an optimal level of loss that positively affects Per Capita Income growth, after reaching this point the effect becomes negative. This result can be seen in Table 6, as follows:

Table 6. Growth and commercial loss due to piracy - developed countries

\begin{tabular}{|c|c|c|c|c|c|}
\hline & (1) & (2) & (3) & (4) & (5) \\
\hline \multirow[t]{2}{*}{ gdi } & $0.3176^{* * *}$ & $0.3140^{* * * *}$ & $0.3211^{* * *}$ & $0.3149^{* * * *}$ & $0.3154^{\text {*** }}$ \\
\hline & $(0.0530)$ & $(0.0620)$ & $(0.0532)$ & $(0.0632)$ & $(0.0642)$ \\
\hline \multirow[t]{2}{*}{ geduc } & 0.1552 & 0.1614 & 0.0877 & 0.0969 & 0.0936 \\
\hline & $(0.2307)$ & $(0.2252)$ & (0.1976) & $(0.1900)$ & (0.1884) \\
\hline \multirow[t]{2}{*}{ 1loss } & 0.0787 & 0.0314 & $1.5368^{* *}$ & $1.4882^{* *}$ & $1.4823^{* *}$ \\
\hline & $(0.3908)$ & $(0.3903)$ & $(0.6675)$ & $(0.6409)$ & $(0.6474)$ \\
\hline \multirow[t]{2}{*}{ labgr } & $-0.2759^{* * *}$ & $-0.2762^{* * *}$ & $-0.2866^{* * *}$ & $-0.2873^{* * *}$ & $-0.2865^{* * * *}$ \\
\hline & $(0.0994)$ & $(0.0983)$ & $(0.1012)$ & $(0.0993)$ & (0.0993) \\
\hline \multirow[t]{2}{*}{$\operatorname{lgdppc}$} & & 0.6743 & & 1.1742 & 1.3893 \\
\hline & & (2.9474) & & $(3.0624)$ & (3.3384) \\
\hline \multirow[t]{2}{*}{ 1loss2 } & & & $-0.1863^{* * *}$ & $-0.1906^{* * *}$ & $-0.1935^{* * *}$ \\
\hline & & & $(0.0637)$ & $(0.0657)$ & $(0.0672)$ \\
\hline \multirow[t]{2}{*}{ voice } & & & & & -0.3205 \\
\hline & & & & & $(1.3929)$ \\
\hline \multirow[t]{2}{*}{ rule } & & & & & -0.3391 \\
\hline & & & & & $(1.0524)$ \\
\hline Year Dummies & Yes & Yes & Yes & Yes & Yes \\
\hline$N$ & 684 & 684 & 684 & 684 & 684 \\
\hline $\operatorname{adj} \cdot R^{2}$ & 0.454 & 0.453 & 0.462 & 0.462 & 0.460 \\
\hline
\end{tabular}

Note. Robust Standard Errors between parentheses. * Significant at 10\%, ** significant at 5\%, and *** significant at $1 \%$. We use temporal dummies in all models.

When carrying out the same test for developing countries, only in the (3) model we observe that the term of squared losses is significant and negative. Indicating that the effect of commercial losses can be beneficial up to a certain time, but from a certain amount onward that value not billed by the companies result in a negative impact on per capita product. 
Table 7. Growth and commercial loss with piracy - developing countries

\begin{tabular}{|c|c|c|c|c|c|}
\hline & $(1)$ & $(2)$ & (3) & (4) & $(5)$ \\
\hline \multirow[t]{2}{*}{ gdi } & $0.3886^{* *}$ & $0.4246^{* * *}$ & $0.4082^{* * *}$ & $0.4245^{* * *}$ & $0.4108^{* * *}$ \\
\hline & $(0.1404)$ & $(0.1432)$ & $(0.1386)$ & $(0.1423)$ & $(0.1390)$ \\
\hline \multirow[t]{2}{*}{ geduc } & -0.7657 & -0.5008 & -0.7495 & -0.5663 & $-0.6792^{*}$ \\
\hline & $(0.5453)$ & $(0.3873)$ & $(0.4525)$ & $(0.3895)$ & $(0.3569)$ \\
\hline \multirow[t]{2}{*}{ lloss } & -0.4676 & -0.2068 & 0.4093 & 0.1626 & 0.5308 \\
\hline & $(0.8191)$ & $(0.7815)$ & $(0.8903)$ & (0.9904) & (1.0271) \\
\hline \multirow[t]{2}{*}{ labgr } & -0.3515 & -0.2682 & -0.3783 & -0.3049 & -0.3409 \\
\hline & $(0.3444)$ & $(0.3558)$ & $(0.3595)$ & $(0.3817)$ & $(0.4036)$ \\
\hline \multirow[t]{2}{*}{$\operatorname{lgdppc}$} & & $-5.2067^{* * *}$ & & -3.7598 & -1.8280 \\
\hline & & $(1.6685)$ & & (2.7706) & (3.8527) \\
\hline \multirow[t]{2}{*}{ lloss2 } & & & $-0.1322^{* *}$ & -0.0666 & -0.1461 \\
\hline & & & $(0.0619)$ & $(0.0920)$ & $(0.1221)$ \\
\hline \multirow[t]{2}{*}{ voice } & & & & & 4.1029 \\
\hline & & & & & (2.6976) \\
\hline \multirow[t]{2}{*}{ rule } & & & & & -2.7603 \\
\hline & & & & & $(2.8223)$ \\
\hline Year Dummies & Yes & Yes & Yes & Yes & Yes \\
\hline$N$ & 186 & 186 & 186 & 186 & 186 \\
\hline $\operatorname{adj} . R^{2}$ & 0.246 & 0.252 & 0.250 & 0.249 & 0.258 \\
\hline
\end{tabular}

Note. Robust Standard Errors between parentheses. * Significant at 10\%,** significant at 5\%, and *** significant at $1 \%$. We use temporal dummies in all models.

In short, the results showed to be in some way aligned with Andrés and Goel (2012), although the estimates are more robust. Software piracy has a negative and significant effect on the growth of the product. According to the estimates, these variables seem to have a convexity relation. The loss of commercial value due to the use of non-licensed software presents a positive effect on the growth of the per-capita income, but its quadratic term presents a negative sign indicating a possible concave relation. When sub-samples are performed for developed countries and developing countries, it was noticed that the effects are repeated only in the developed countries.

\section{Final Remarks}

This study proposed to evaluate the impact of software piracy on economic growth using data for 95 countries in the years 2000-2014, with data from the Business Software Alliance and the World Bank. According to the literature, piracy is responsible for impacts on growth through different channels, summarized through human capital. On the other hand, it generates positive externalities that can, among other things, increase the general well-being of society, thus presenting a positive relationship with growth. Some authors in the literature lecture on the importance of including human capital in the growth models, while others analyze the relation through the protection of copyright (Ginarte \& Park, 1997; Falvey, Foster, \& Greenaway, 2006; Kim, Lee, \& Park, 2012). The results found are in the same direction as the study of Andrés and Goel (2012), although with a more robust statistic and that can be interpreted as causality. Piracy possesses a negative and significant effect on GDP growth, essentially for developed countries.

Even so, like the authors, the relation seems to present itself as convex. The results remained statistically significant when controlled by an education variable. Moreover, the loss of commercial value of software positively affects per capita income, but its results indicate a possible concave relationship. These results were repeated only in the results of the regressions for developed countries, but not for developing ones, which may indicate that more developed software markets and, therefore, with greater protection of intellectual rights, are easier to benefit from the effects of piracy.

Finally, for a new research agenda, it would be interesting to investigate the determinants of piracy, since, knowing the effects of piracy and understanding its causes, governments and leaders can work on policies to minimize the negative effects and take more advantage of the positive ones, thereby increasing the aggregate benefit of piracy on society.

\section{References}

Andrés, R., \& Goel, R. K. (2012). Does software piracy affect economic growth? Evidence across countries. 
Journal of Policy Modeling, (34), 284-295. https://doi.org/10.1016/j.jpolmod.2011.08.014

Bae, S. H., \& Choi, J. P. (2006) A model of piracy. Information Economics and Policy, 18, 303-320. https://doi.org/10.1016/j.infoecopol.2006.02.002

Banerjee, A. (1992) A simple model of herd behavior. Quarterly Journal of Economics, 57(3), 797-818. https://doi.org/10.2307/2118364

Banerjee, D., \& Chatterjee, I. (2010). The impact of piracy on innovation in the presence of technological and market uncertainty. Information Economics and Policy, 22, 391-397. https://doi.org/10.1016/j.infoecopol.2010.09.005

Barro, R. (2001). Human Capital and Growth. American Economic Review, 91(2), 12-17.

Barro, R., \& Lee, J. W. (1994). Sources of Economic Growth. Carnegie Conference Series on Public Policy, 40(1).

Becker, G. S. (1964). Human capital: A theoretical and empirical analysis, with special reference to education. New York, Columbia University Press.

Becker, G. S. (1974). Crime and punishment: An Economic Approach. Essays in the Economics of Crime and Punishment, 1-54.

Bezmen, T. L., \& Depken, C. A. (n. d.). The impact of software piracy on economic development. Working paper. Francis Marion University.

Business Software Alliance. (2007). Piracy study, Fifth Annual BSA and IDC Global Software.

Business Software Alliance. (2013). The Compliance Gap: BSA global software survey. Retrieved from http://globalstudy.bsa.org/2013/downloads/studies/2013GlobalSurvey_Study_en.pdf

Business Software Alliance. (n. d.). What is software piracy? Retrieved from http://www.bsa.org/Piracy\%20Portal.aspx

Castro, J. O. D., Balkin, D. B., \& Shepherd, D. A. (2008). Can entrepreneurial firms benefit from product piracy? Journal of Business Venturing, 23, 75-90. http://dx.doi.org/10.1016/j.jbusvent.2005.07.003

Falvey, R., Foster, N., \& Greenway, D. (2006). Intellectual property rights and economic growth. Review of $\begin{array}{lr}\text { Development } & \text { Economics, } \\ \text { https://onlinelibrary.wiley.com/doi/pdf/10.1111/j.1465-7287.1997.tb00477.x }\end{array}$

Ginarte, J. C., \& Park, W. G. (1997). Intellectual property rights and economic growth. Contemporary Economic Policy, 15, 51-61. $\quad$ Retrieved from https://onlinelibrary.wiley.com/doi/pdf/10.1111/j.1465-7287.1997.tb00477.x

Glaeser, E., La Porta, R., Lopez De Silanes, F., \& Shleifer, A. (2004). Do institutions cause growth? Journal of Economic Growth, 271-303. Retrieved from https://link.springer.com/article/10.1023/B:JOEG.0000038933.16398.ed

Gomes, N. D., Cerqueira, P. A., \&Almeida, L. A. (2015). A survey on software piracy empirical literature: Stylized facts and theory. Information Economics and Policy, 32, 29-37. https://doi.org/10.1016/j.infoecopol.2015.07.008

Jaisingh, J. (2009). Impact of piracy on innovation at software firms and implications for piracy policy. Decision Support Systems, 46, 763-773. https://doi.org/10.1016/j.dss.2008.11.018

Jeong, B. K., \& Khouja, M. (2013). Analysis of the effectiveness of preventive and deterrent piracy control strategies: Agent-based modeling approach. Computers in Human Behavior, 29, 2744-2755. https://doi.org/10.1016/j.chb.2013.07.029

Kim, Y. K., Lee, K., \& Park, W. G. (2012). Appropriate Intellectual Property Protection and Economic Growth in Countries at Different Levels of Development. Research Policy, 41(2), 358-375. http://dx.doi.org/10.1016/j.respol.2011.09.003

King, S. P., \& Lampe, R. (2003). Network externalities, price discrimination and profitable piracy. Information Economics and Policy, 15, 271-290. https://doi.org/10.1016/S0167-6245(02)00110-5

Kogan, K., Ozinci, Y., \& Perlman, Y. (2013). Containing piracy with product pricing, updating and protection investments. International Journal of Production Economics, 144, 468-478. https://doi.org/10.1016/j.ijpe.2013.03.018 
Liu, Y., Cheng, H. K., Tang, Q. C., \& Eryarsoy, E. (2011). Optimal software pricing in the presence of piracy and word-of-mouth effect. Decision Support Systems, 51, 99-107. https://doi.org/10.1016/j.dss.2010.11.032

Lucas, R. E. (1988). On the mechanics of economic development. Journal of Monetary Economics, 22, 3-42.

Mauro, P. (1992). Corruption and Growth. The Quarterly Journal of Economics, 110(3), 681-712.

Minniti, A., \& Vergari, C. (2010). Turning Piracy into Profits: A Theoretical Investigation. Information Economics and Policy, 22, 379-390. http://dx.doi.org/10.1016/j.infoecopol.2010.06.001

Prasad, A., \& Mahajan, V. (2003). How many pirates should a software firm tolerate? An analysis of piracy protection on the diffusion of software. International Journal of Research in Marketing, 20, 337-353. https://doi.org/10.1016/j.ijresmar.2003.02.001

Rao, P. M., \& Klein, J. A. (1994). Growing Importance of Marketing Strategies for the Software Industry. Industrial Marketing Management, 23, 29-37. https://doi.org/10.1016/0019-8501(94)90024-8

Romer, P. M. (1990) Endogenous Technological Change. The Journal of Political Economy, 98(5), 71-102. Retrieved from https://www.journals.uchicago.edu/doi/abs/10.1086/261725

Sánchez, F. M. (2010). Avoiding commercial piracy. Information Economics and Policy, 22, 398-408. https://doi.org/10.1016/j.infoecopol.2010.07.002

Schultz, T. W. (1963). Economic Value of Education. New York: Columbia University Press.

SIIA. (2000). SIIA report on global software piracy 2000. Washington, DC: Software and Information Industry Association.

Waters, J. (2015). Welfare implications of piracy with dynamic pricing and heterogeneous consumers. European Journal of Operational Research, 240, 904-911. http://dx.doi.org/10.1016/j.ejor.2014.08.022

Yang, D. (2007) The impact of business environments on software piracy. Technology in Society, 29, 121-141. https://doi.org/10.1016/j.techsoc.2006.10.006

\section{Note}

Note 1. Banerjee (1992) has defined herding effect as an economic and social situation in which our behavior is affected by the others. In the same way, individual decisions are based on the choices done by similars.

\section{Copyrights}

Copyright for this article is retained by the author(s), with first publication rights granted to the journal.

This is an open-access article distributed under the terms and conditions of the Creative Commons Attribution license (http://creativecommons.org/licenses/by/4.0/). 